\title{
The relationship between the massive nesting of the olive ridley sea turtle (Lepidochelys olivacea) and the local physical environment at La Escobilla, Oaxaca, Mexico, during 2005
}

\section{La relación entre las arribadas de la tortuga golfina (Lepidochelys olivacea) y el ambiente físico en La Escobilla, Oaxaca, México durante 2005}

\author{
Erik Coria-Monter and Elizabeth Durán-Campos
}

Becarios Posdoctorales. Instituto de Ciencias del Mar y Limnología. Universidad Nacional Autónoma de México. Circuito exterior s/n, Ciudad Universitaria, CDMX, Del. Coyoacán, CP 04510. México e-mail: erikcmonter@gmail.com

Recibido: 16 de mayo de 2016.

Aceptado: 9 de mayo de 2017.

Coria-Monter E. and E. Durán-Campos. 2017. The relationship between the massive nesting of the olive ridley sea turtle (Lepidochelys olivacea) and the local physical environment at La Escobilla, Oaxaca, Mexico, during 2005. Hidrobiológica 27 (2): 201-209. D0l: 10.24275/uam/izt/dcbs/hidro/2017v27n2/Coria

\begin{abstract}
Background. Sea turtles of the genus Lepidochelys exhibit a complex and synchronous mass-nesting behavior termed "arribada." Goals. This paper analyzes the local physical environment during the arribada events that occurred in 2005 at La Escobilla, Oaxaca, Mexico. Methods. Daily night patrols were conducted from May to November 2005, along the nesting zone. Daily records for air temperature and rainfall were obtained from the automatic weather station by the Comisión Nacional del Agua. Sea surface temperature and salinity fields were obtained from the Hybrid Coordinate Ocean Model (HYCOM), and surface ocean currents were obtained from the Asia-Pacific Data Research Center. Results. The analyses showed five arribada events during the period. A common feature was the presence of eddies and strong currents at the beginning of each arribada. A correlation of statistical significance was observed between the abundance of the arribada and the current speed $\left(R=0.93, R^{2}=0.86, p=0.04\right)$. The correlation with salinity showed values of $R=0.55, R^{2}=0.31$, $p=0.32$, whereas correlation with rainfall was $\mathrm{R}=0.53, \mathrm{R}^{2}=0.28, p=0.14$. A weak correlation was observed with air temperature $\left(R=0.35, R^{2}=0.12, p=0.59\right)$ and with sea surface temperature $\left(R=0.23, R^{2}=0.05, p=0.66\right)$. Conclusions. Although sea turtles are strong swimmers, the proximity to favorable oceanic currents generated by eddies might be related to the beginning of the arribada, considering that this current might provide energy savings and accumulate chemical compounds and food in the water column.
\end{abstract}

Key words: Arribada, eddies, La Escobilla, Lepidochelys olivacea.

\section{RESUMEN}

Antecedentes. Las tortugas marinas del género Lepidochelys presentan un complejo comportamiento de anidamiento masivo conocido como arribada. Objetivos. El presente trabajo analiza la relación entre el ambiente físico durante los eventos de arribada ocurridos en 2005 en La Escobilla, Oaxaca, México. Métodos. Se realizaron patrullajes nocturnos de mayo a noviembre de 2005 y se obtuvieron registros de temperatura del aire y precipitación del radar meteorológico de CONAGUA. Mapas de salinidad y temperatura superficial del mar fueron obtenidos a partir del modelo HYCOM. Las corrientes superficiales fueron determinadas a partir de bases de datos disponibles por Centros de Investigación en dinámica oceanográfica internacionales. Resultados. Se observaron cinco eventos de arribada. Una característica importante fue la presencia de vórtices y corrientes intensas durante su inicio. Se observó una correlación estadísticamente significativa entre las arribadas y la velocidad de las corrientes $\left(R=0.93, R^{2}=0.86, p=0.04\right)$. La correlación con la salinidad mostró valores de $\mathrm{R}=0.55, \mathrm{R}^{2}=0.31, p=0.32$, mientras que la correlación con la precipitación fue $\mathrm{R}=0.53$, $\mathrm{R}^{2}=0.28, p=0.14$. Se observó una correlación débil con la temperatura del aire $\left(\mathrm{R}=0.35, \mathrm{R}^{2}=0.12, p=0.59\right)$ y con la temperatura superficie del mar $\left(R=0.23, R^{2}=0.05, p=0.66\right)$. Conclusiones. A pesar de que las tortugas marinas son fuertes nadadoras, la proximidad a corrientes favorables generadas por los vórtices podría estar relacionada con el inicio de la arribada, considerando que estas corrientes asegurarían un ahorro en energía y su presencia podría acumular compuestos químicos y comida en la columna de agua.

Palabras clave: Arribada, La Escobilla, Lepidochelys olivacea, vórtices. 


\section{INTRODUCTION}

Sea turtles are widely distributed throughout the world's oceans, from tropical to temperate waters. The olive ridley sea turtle (Lepidochelys olivacea, Eschscholtz, 1829) is a widely distributed species listed by the International Union for Conservation of Nature as vulnerable (IUCN, 2012) and similar to the Kemp's ridley (Lepidochelys kempii, Garman, 1880.) It undertakes synchronous mass nesting, known as "arribada" or "arribazón" (Shanker et al., 2003; Valverde et al., 2012). The arribadas are complex and massive nesting phenomena that involve tens of thousands to hundreds of thousands of females that nest synchronously over a few nights (Valverde et al., 1998).

These phenomena have been documented only in a few countries of the world. Nesting aggregates of over 100,000 females have been reported in the Pacific of Mexico (Márquez et al., 1976; Márquez et al., 2005), the Pacific of Costa Rica (Pritchard, 1997; Pandav et al., 1998; Fonseca et al., 2009), and at Orissa on the east coast of India (Shanker et al., 2003).

On the American continent, the most numerous specimens of this turtle arrive at the coasts of Costa Rica and Mexico, where spectacular reproductive habitats are located. In Costa Rica, females typically nest at night, usually once a month, with a single arribada lasting from 2-10 nights (Cornelius, 1982; Fonseca et al., 2009). In Mexico, one of the major world nesting sites for this species is La Escobilla, Oaxaca, where about one-million nests per year occur during each season (PeñafloresSalazar et al., 2000; Márquez et al., 2005). Some hypotheses have been proposed concerning the causes of the arribada, which include the sand granulometric characteristics of the nesting sites (Clusella-Trullas \& Paladino, 2007), fitness benefits to nests, and behaviors to avoid predation (Pritchard, 1997; Bernardo \& Plotkin, 2007); however, the factors that cause these events remain unclear.
In general, the arribadas occur once a month, at a particular time of year; however, in some cases, they occur less frequently than once a month. Occasionally, an arribada lasts for a single day or as long as 30 days (Ballestero, 1996). In the eastern Pacific, the arribadas coincide annually with the rainy season (Cornelius, 1986), but in the northern Indian Ocean, they coincide with the dry season (Dash \& Kar, 1990).

The aim of this study was to analyze the relationship between the local physical environment (air temperature, rainfall, salinity, sea surface temperature, and surface ocean currents) during the arribada events that occurred in 2005 at La Escobilla, Oaxaca, Mexico. As one of the largest olive ridley arribada sites in the world, La Escobilla, is an ideal location to consider how some physical factors might relate to the initiation of these events.

\section{MATERIAL AND METHODS}

La Escobilla is located on the Mexican Pacific Coast between Puerto Escondido and Puerto Ángel, Oaxaca, (1547.1' N, 96 44.3' W) (Fig. 1). The beach is at the western end of a long beach of $\sim 22 \mathrm{~km}$. The nesting zone has a length of $\sim 8 \mathrm{~km}$, has been monitored by the Mexican government since 1967, and is now considered a national sanctuary protected area. The area is divided laterally into $100-\mathrm{m}$ wide stations with markers every $50 \mathrm{~m}$.

During the period between May and November 2005, daily night patrols were conducted along the nesting zone. Although the data do not include all of 2005, they are representative for the nesting season, considering that the arribadas on this beach are more common from March to May and more intense from August to September (PeñafloresSalazar et al., 2000). We used the criterion of Valverde et al. (1998), who define an arribada as the presence of 100 or more females on the beach at any given time within a 24 -hour period. During each event,

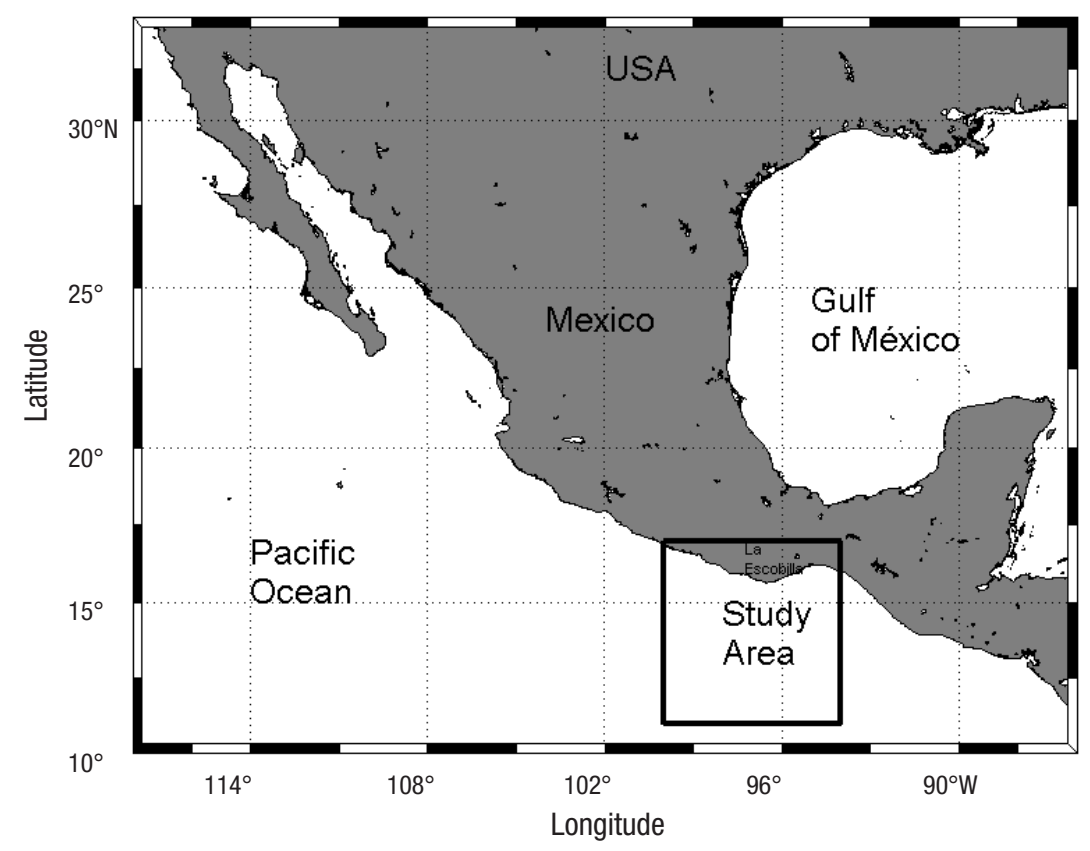

Figure 1. Study area. La Escobilla, Oaxaca, Mexico. The rectangle represents the domain of interest. 
females were counted following the Márquez \& Van Dissell (1982) method, which is based on the number of females on the beach every hour, estimating the number of active females in a previously established sampling area, and extrapolating the results for the total area.

During the same period, daily mean air temperature and rainfall records were obtained from the automatic weather station of the Comisión Nacional del Agua (CONAGUA), situated at Puerto Ángel, Oaxaca, 91 meters above sea level.

Sea surface temperature (SST) $\left({ }^{\circ} \mathrm{C}\right.$ ) and salinity (psu) data at $2 \mathrm{~m}$ depth were obtained from the output of the Hybrid Coordinate Ocean Model (HYCOM) during each arribada event. HYCOM has a resolution of $1 / 12$ degree in the horizontal and uses hybrid (isopycnal/sigma/z-level) coordinates in the vertical. The output is interpolated onto a regular $1 / 12$ degree grid horizontally and 40 standard depth levels. The output data obtained by this model have been widely used to reproduce the dynamics in the upper layers $(<2000 \mathrm{~m})$ in different domains, and it is known that the data can be comparable with in situ measurements (Thacker et al., 2004; Chassignet et al., 2007; Castellanos et al., 2016)

The surface current fields $\left(\mathrm{m} \mathrm{s}^{-1}\right)$ were obtained from the Asia-Pacific Data Research Center (APDRC) of the International Pacific Research Center (IPRC), at the University of Hawaii (http://apdrc.soest.hawaii. edu/data/data.php, downloaded May 13, 2015.)

Because our data present a normal distribution, a Pearson's parametric correlation and regression were performed in order to analyze the magnitude of the association as well as the relationship between the abundance of the turtles observed during the arribada events and the environmental variables (air temperature, rainfall, salinity, SST, and the current speed). All analyses were performed using Statistica v. 8.0 software (StatSoft, Inc., Tulsa, OK, USA).

\section{RESULTS}

We observed five arribada events during the study period. The first occurred from May 9-14, the number of turtles counted ranged from 111 to 11,313 per day, with a total number of 28,237 (mean $\pm \mathrm{SE}=4,709 \pm$ 1,877). (Fig. 2a) During this six-day period, the air temperature ranged from 28.85 to $30.10^{\circ} \mathrm{C}$ (mean $\pm \mathrm{SE}=30.00 \pm 0.19^{\circ} \mathrm{C}$ ) (Fig. 2b) and the rainfall was zero (Fig. 2c). The salinity field showed a variation from 33.9 to $34.6 \mathrm{psu}$ (Fig. 3a), whereas the SST rose in a range from 26.3 to $31.7^{\circ} \mathrm{C}$, showing two warm cores in the west and east portions, as well as a cold core in the central region of the study area (Fig. 4a). During this arribada, the surface currents showed the presence of a strong cyclonic eddy located between $12.7^{\circ}$ and $14.2^{\circ} \mathrm{N}$ latitude and $94.5^{\circ}$ to $96.9^{\circ} \mathrm{W}$ longitude, which induced the formation of two anticyclonic eddies that were in agreement with the SST distribution. Strong currents were observed at the boundaries of these eddies, with speeds of $\sim 0.8 \mathrm{~m} \mathrm{~s}^{-1}$, as well as a strong current from south to north (Fig. 5a).

The second event was the shortest and occurred from July 16-19; the number of turtles counted ranged from 114 to 24,588 with a total number of 39,691 (mean $\pm \mathrm{SE}=9,923 \pm 5,993$ ) (Fig. 2d). During this four-day event, the air temperature range was between 27.30 to 28.65 ${ }^{\circ} \mathrm{C}\left(\right.$ mean $\pm \mathrm{SE}=28.0 \pm 0.6^{\circ} \mathrm{C}$ ) (Fig. 2e) and the rainfall from 0 to 10.1 $\mathrm{mm}$ (mean $\pm \mathrm{SE}=3 \pm 2.48$ ) (Fig. 2f). During this event, the salinity varied from 33.3 to 34.1 psu (Fig. $3 \mathrm{~b}$ ) and the SST ranged from 27.2 to $31.8^{\circ} \mathrm{C}$, with a warm core close to the coast at the western portion of the study area (Fig. 4b). During this arribada, an eddy triad (cyclonic-anticyclonic-cyclonic) dominated the surface current. Both cyclonic structures showed maximum velocities of $\sim 0.8 \mathrm{~m} \mathrm{~s}^{-1}$ at their periphery. The anticyclonic eddy was close to the coast and had a velocity of $\sim 0.3$ $\mathrm{m} \mathrm{s}^{-1}$ (Fig. 5b).

The third event occurred from August 10-16. The number of turtles counted ranged from 147 to 80,136 , with a total number of 197,635 (mean $\pm \mathrm{SE}=28,234 \pm 13,184$ ) (Fig 2g). The air temperature during the seven-day period ranged from 27.25 to $30.40{ }^{\circ} \mathrm{C}$ (mean $\pm \mathrm{SE}=$ $29.00 \pm 0.96{ }^{\circ} \mathrm{C}$ ) (Fig. 2h) and the rainfall was between 0.5 and 3.0 $\mathrm{mm}$ (mean $\pm \mathrm{SE}=1.00 \pm 0.38$ ) (Fig. 2i). The salinity varied from 33.4 to $34.4 \mathrm{psu}$ (Fig. 3c), whereas the SST rose in a range from 27.0 to 32.2 ${ }^{\circ} \mathrm{C}$, showing warm surface water that extended along the coast at the western portion of the study area (Fig. 4c). The surface current during this arribada showed the presence of an anticyclonic eddy close to the coast with a velocity of $\sim 0.7 \mathrm{~m} \mathrm{~s}^{-1}$, as well as the presence of a weak mesoscale cyclonic eddy with a diameter $\sim 30 \mathrm{~km}$ centered at $13^{\circ} \mathrm{N}$ latitude. A strong current was observed between both structures that flowed close to the coast northeast to southwest (Fig. 5c).

The fourth event was the largest during the period studied, from August 30 to September 6 . The number of turtles counted ranged from 127 to 88,430 , with a total number of 317,219 (mean \pm SE $=39,652$ $\pm 13,133$ ) (Fig. 2j). The air temperature during this event ranged from 26.45 to $29.25^{\circ} \mathrm{C}$ (mean $\pm \mathrm{SE}=28.00 \pm 0.32{ }^{\circ} \mathrm{C}$ ) (Fig. $2 \mathrm{k}$ ) and the rainfall was between 0 to $93.6 \mathrm{~mm}$ (mean $\pm \mathrm{SE}=21.00 \pm 11.65$ ) (Fig. 2I). The salinity values ranged from 33.2 to 34.0 psu (Fig. $3 \mathrm{~d}$ ) and the SST ranged from 27.7 to $32.2^{\circ} \mathrm{C}$, showing a warm core associated with a cold core (Fig. 4d). The surface currents during this event showed the presence of a strong pair of eddies (anticyclonic-cyclonic) which coincided with the temperature distribution and strong currents that were observed between both structures flowing northeast to southwest with a velocity of up to $1 \mathrm{~m} \mathrm{~s}^{-1}$ (Fig. $5 \mathrm{~d}$ ).

The final event observed during our study period occurred November 2-6, when the number of turtles counted ranged from 171 to 118,406 , with a total number of 296,268 (mean \pm SE $=42,324 \pm$ 19,733) (Fig. $2 \mathrm{~m}$ ). The air temperature ranged from 28.05 to $29.25^{\circ} \mathrm{C}$ (mean $\pm \mathrm{SE}=29.00 \pm 0.16$ ) (Fig. $2 \mathrm{n}$ ) and the rainfall was zero (Fig. 20). During this event the salinity variation was 33.2 to 34.2 psu (Fig. 3e) and the SST rose in a range from 21.8 to $30.4{ }^{\circ} \mathrm{C}$, showing that a cold current extended more than $400 \mathrm{~km}$ from the coast; this current induce the formation of a core with a strong gradient in temperature (Fig. 4e). On the first day of this arribada, the surface currents were dominated by the presence of a strong anticyclonic eddy close to the coast, centered at $13.5^{\circ} \mathrm{N}$ latitude and $98 \mathrm{~W}$ longitude, with velocities that reached $1 \mathrm{~m}$ $\mathrm{s}^{-1}$. Strong currents $\left(\sim 1 \mathrm{~m} \mathrm{~s}^{-1}\right)$ were observed in association with this eddy flowing close to the coast from north to south (Fig. 5e).

Based on our results, statistical analyses were performed in order to test the relationships between the abundance of the arribada and the environmental variables (air temperature, rainfall, salinity, SST, and the current speed). A correlation of statistical significance was observed between the abundance of the arribada and the speed of the currents ( $R$ $\left.=0.93, \mathrm{R}^{2}=0.86, p=0.04\right)$. The correlation with salinity showed values of $\mathrm{R}=0.55, \mathrm{R}^{2}=0.31, p=0.32$, whereas correlation with rainfall was $\mathrm{R}=0.53, \mathrm{R}^{2}=0.28, p=0.14$. A weak correlation was observed with air temperature $\left(\mathrm{R}=0.35, \mathrm{R}^{2}=0.12, p=0.59\right)$ and with SST $(\mathrm{R}=0.23$, $\left.\mathrm{R}^{2}=0.05, p=0.66\right)$. 


\section{DISCUSSION}

The proximate cues that induce the arribada have been widely hypothesized. One prevailing hypothesis asserts that an arribada begins when there is a strong onshore wind (Hendrickson, 1980); however, they can also occur in the absence of wind. The lunar cycle has been suggested to be essential for initiating an arribada, considering that the olive ridley arribada in the eastern Pacific frequently coincide with the third-quarter moon (Bernardo \& Plotkin, 2007), but they also occur during other lunar phases (Ballestero, 1996). Evidence also shows that arribadas begin at about the time of high tide (Plotkin, 1994). Females that normally emerge synchronously on Nancite Beach, Costa Rica to oviposit, delayed oviposition in response to a period of extreme rainfall $(52.98 \mathrm{~cm})$ (Plotkin et al., 1997). Our observations, however, showed that the largest and most intense arribada event ("arribada" 4) occurred during a period of maximum rainfall, which suggests that normal levels

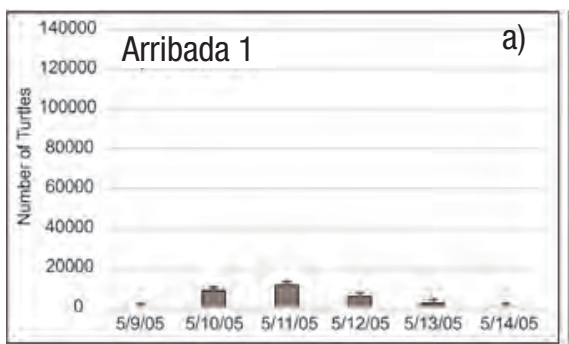
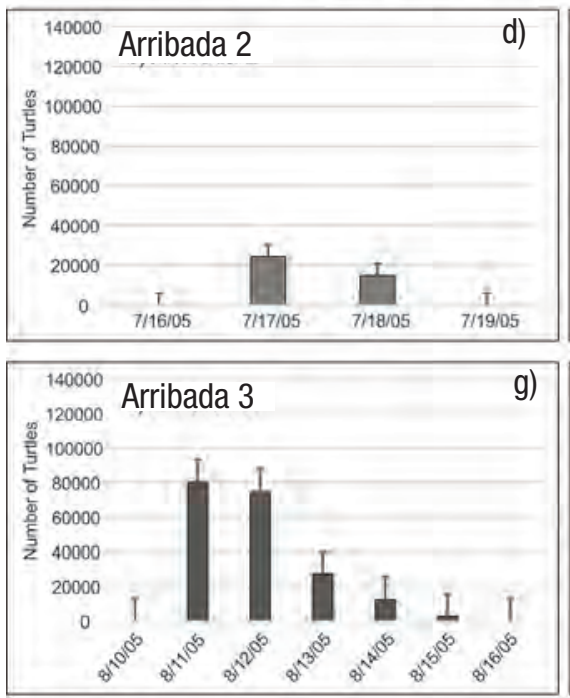

g)

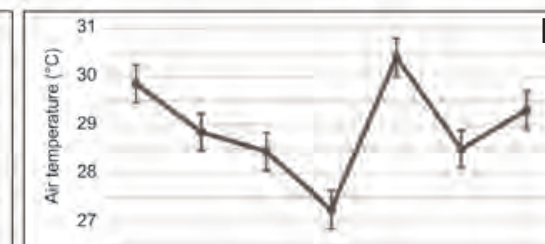

26
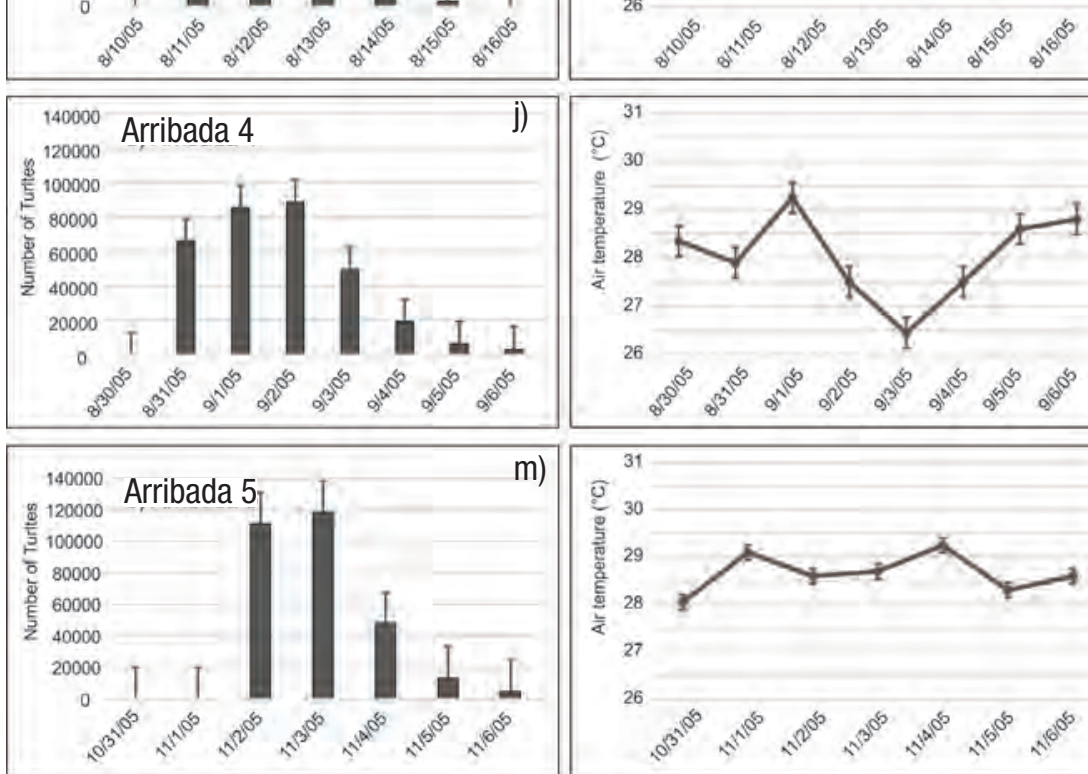
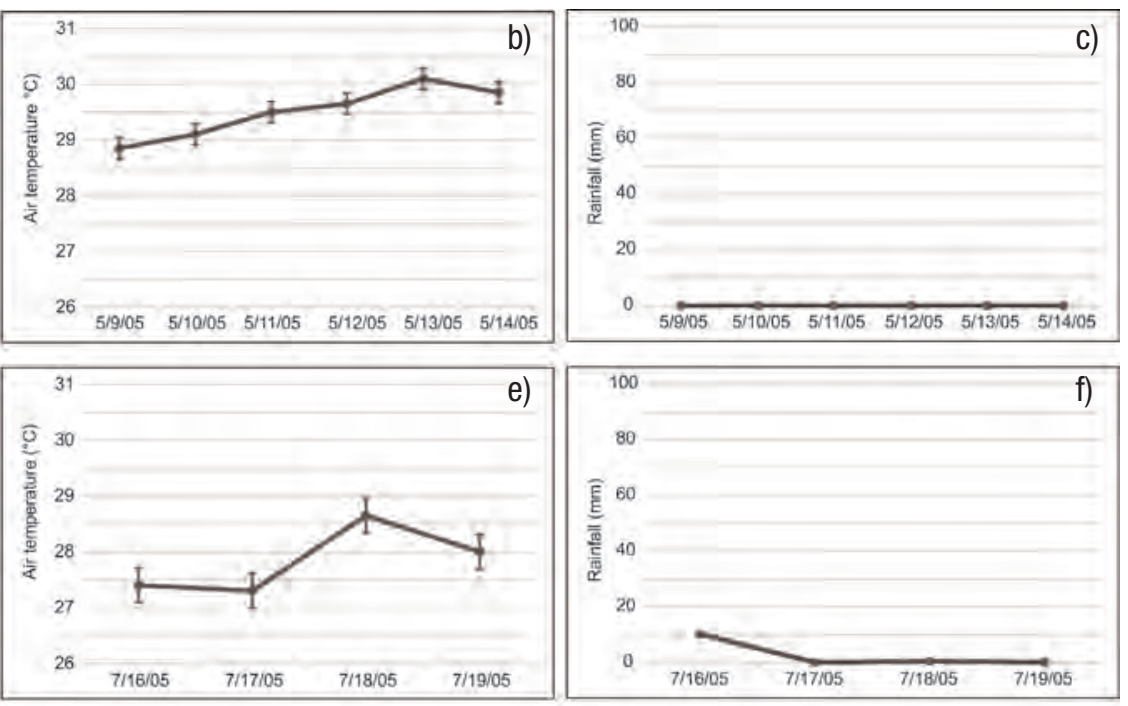

h)
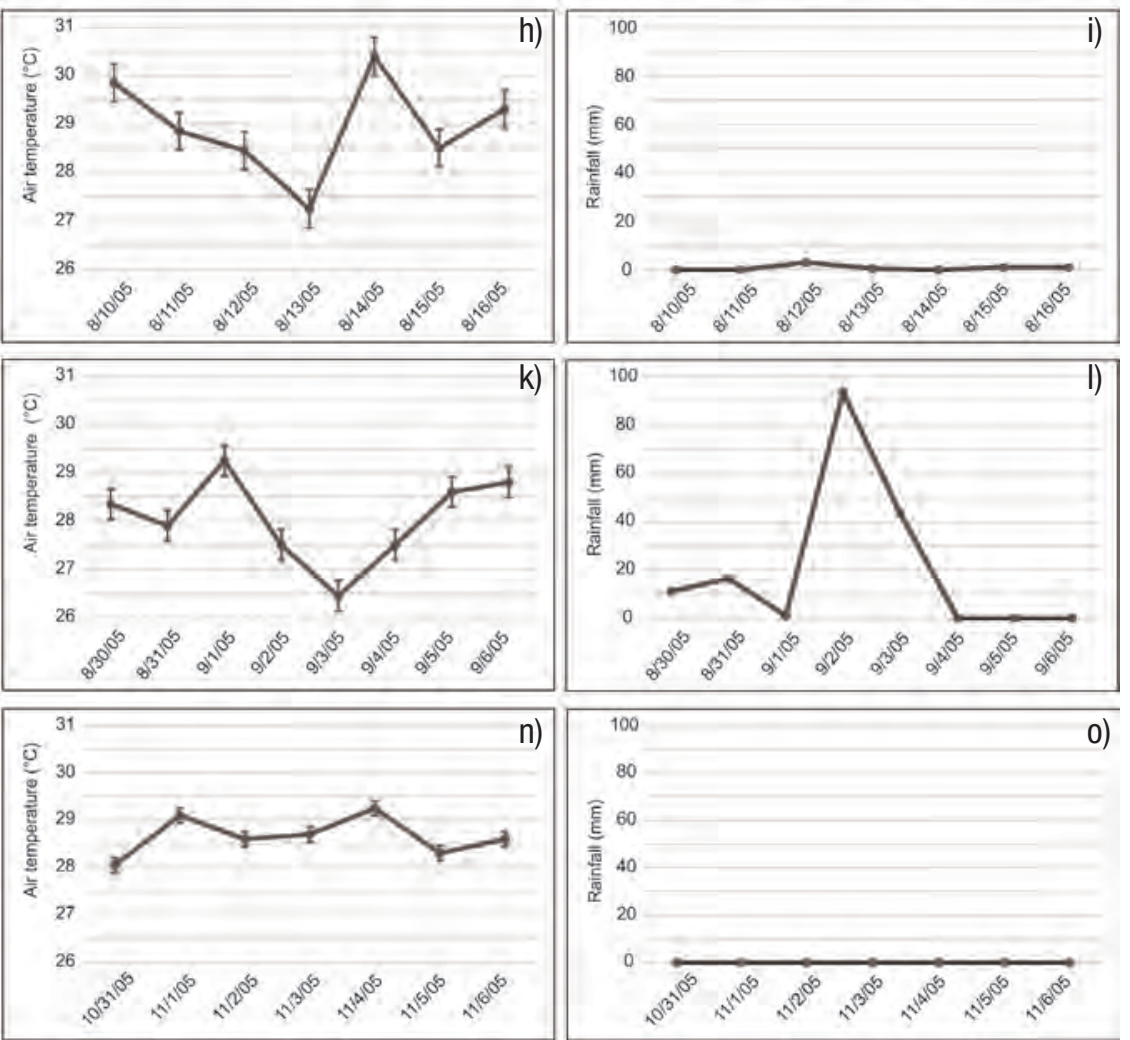

Figures 2a-0. Number of turtles, air temperature $\left({ }^{\circ} \mathrm{C}\right)$ and rainfall $(\mathrm{mm})$ observed during the arribada events at La Escobilla, 0axaca during 2005. a-c) "arribada" 1 , d-f) "arribada" 2, g-i) "arribada" 3, j-I) "arribada" 4, m-0) "arribada" 5. Bars represents \pm 1 standard error (SE). 
of rainfall do not adversely affect the arribada. The air temperature in this study appeared not to affect significantly the arribada. Cornelius (1991) also reported the lack of correlation between air temperature and arribada timing. Because salinity can vary substantially and rapidly in response to rainfall, it seems to have no significant effect on the timing of the arribada.

Previous studies have shown the effect of SST on the ecology of the sea turtles. Solow et al. (2002) identifies a significant effect of the SST on the re-migration interval in the largest Atlantic population of green turtles (Chelonia mydas, Linnaeus, 1758). Using SST satellite and aerial survey data, Coles \& Lusick (2000) suggest that the sea turtles are not randomly distributed geographically but stay within preferred temperature ranges that are seasonally variable. Other studies, however, indicate that sea turtles do not follow specific isotherms during migrations and do not make turns en route where specific thermal cues were encountered, suggesting that SST plays a minimal role in influencing the migration/aggregation of the sea turtles (Luschi et al., 1998; Hays et al., 2001). These results seem to coincide with our observations, given that no significant correlation between SST and the arribada was observed. It is important to keep in mind, however, that in 2005 the Pa- cific Ocean was characterized by an anomaly in SST (Lluch-Cota et al., 2013), which may have affected the dynamics of the water column and marine populations, including the sea turtles in other aspects.

Based on our results, cyclonic and anticyclonic eddies (cold and warm core, respectively) and strong currents were common features, which might be strongly related with arribada events. These oceanographic processes have been shown to have a remarkable influence on the movements and migrations of sea turtles (Luschi et al., 2003). In particular, juvenile loggerhead (Caretta caretta, Linnaeus, 1758) and olive ridley sea turtles have been observed interacting along the peripheries of eddies in the central North Pacific Ocean, which suggest a foraging advantage associated with the currents generated by the eddies (Polovina et al., 2004). Similar observations in the North Pacific and Gulf of Mexico revealed that sea turtles displayed a preference for foraging areas located at the peripheries of eddies, suggesting that these sites act as "hot spots" (Polovina et al., 2006; Foley et al., 2013). Recently, Gaube et al. (2017) documented the use of mesoscale eddies by juvenile loggerhead sea turtles in the Brazil-Malvinas confluence region. In this area, sea turtles are significantly more likely to be located in the interior of anticyclone eddies as a result of their behavior, suggesting
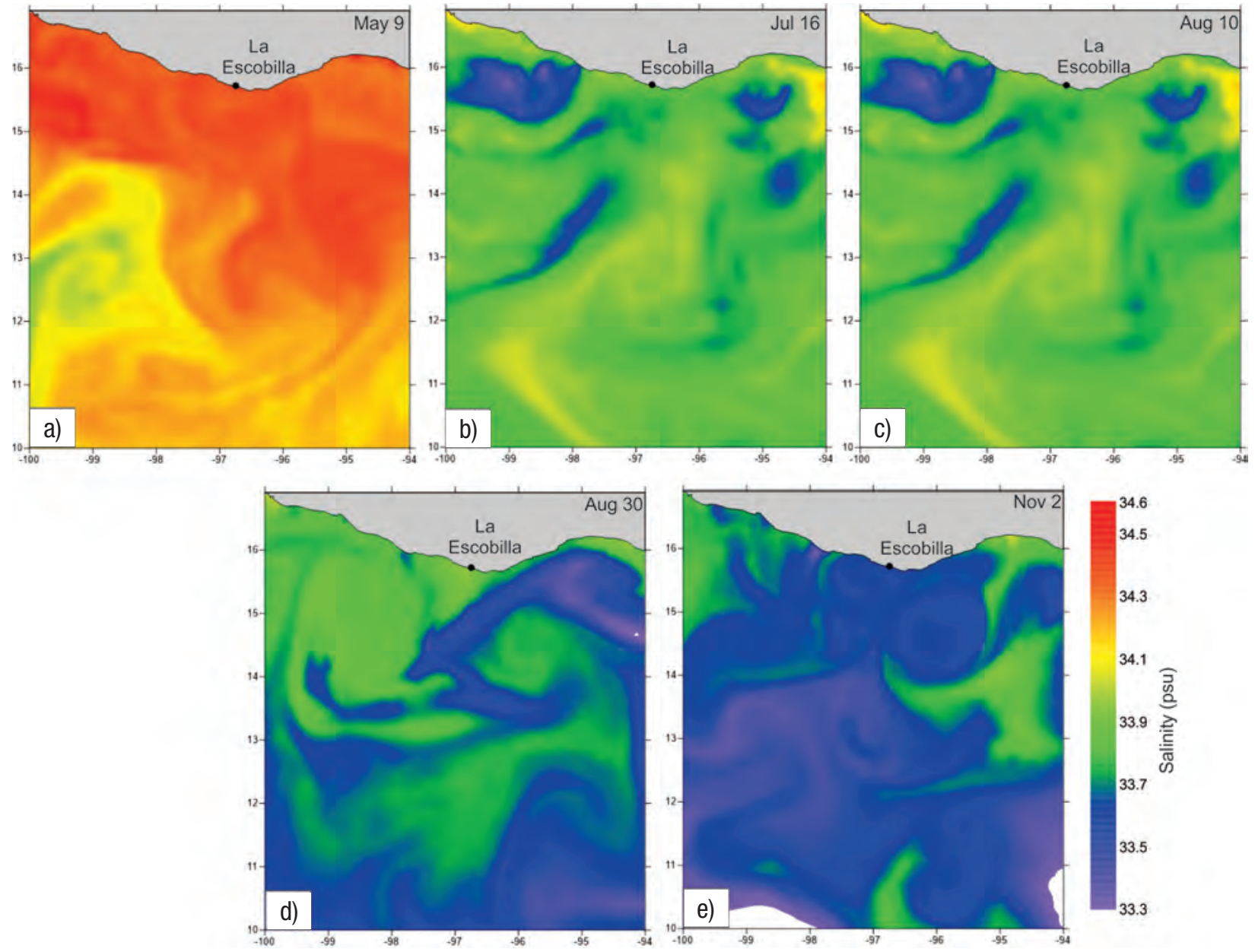

Figures 3a-e. Maps of surface salinity (psu) at each arribada event at La Escobilla, Oaxaca during 2005 on: a) May 9, 2005, b) July 16, 2005, c) August 10, 2005, d) August 30, 2005, e) November 2, 2005 
that these turtles are possibly feeding on prey items associated with low near-surface chlorophyll concentrations observed in those features.

In our particular case, the surface ocean currents and eddies observed at La Escobilla might affect the sea turtle population via three potential mechanisms: 1) The major ocean currents clearly affect turtle movements by producing powerful forces that advect swimming turtles in a given direction, which is not necessarily consistent with the intended swimming direction; 2) The effects at the border of main currents, where strong processes such as eddies or rings often occur, produce mesoscale rotatory drifts of water. These processes can affect sea turtle movements in a manner similar to how bird flight is affected by wind (Richardson, 1990). And 3) It is known that ocean eddies modify the physicochemical properties of the water column and play a fundamental role in transporting chemical compounds, suspended material, nutrients, and organisms (Coria-Monter et al., 2014; DuranCampos et al., 2015). Therefore, the presence of these structures might ensure the availability of food for sea turtles. It has been shown that eddies and tropical instability waves in the eastern tropical Pacific play an important role in the dynamics and biology of the region, and in the transfer of mass, energy, heat, and biological constituents from the shelf to the deep ocean (Palacios \& Bograd, 2005; Willet et al., 2006). The generation, characteristics, and life histories of these processes are closely linked to patterns in the atmosphere (Amador et al., 2006), to local hydrography (Fiedler \& Talley, 2006), and to the ocean circulation in the region (Kessler, 2006). In particular, the anticyclonic eddies in the region have been observed to last up to six months and propagate up to 1500 km offshore (Müller-Karger \& Fuentes-Yaco, 2000).

The observed eddies and surface currents might influence the course and extent of female post-nesting migrations, which vary greatly among different species. For example, the green (Chelonia mydas, Linnaeus, 1758), hawksbill (Eretmochelys imbricata, Linnaeus, 1766), and loggerhead (Caretta caretta, Linnaeus, 1758) turtles shuttle between the nesting beach and specific feeding area used for the entire interreproductive period. In these cases, individuals swim, rather than drift, to complete their journeys, with possible current advection helping them to reach their target rapidly. In particular, the olive ridley turtle has been reported to leave the coastal nesting areas to reach the pelagic environment, where they forage and perform wandering movements. The common lifecycle of sea turtles encompasses prolonged periods in the open ocean where turtles are known to move widely between different habitats or specific locations, ranging over large oceanic areas away from the continental shelf (Musick \& Limpus, 1997). In this environment, currents and related oceanographic features are likely to be important factors that affect behavioral sea turtle movements.
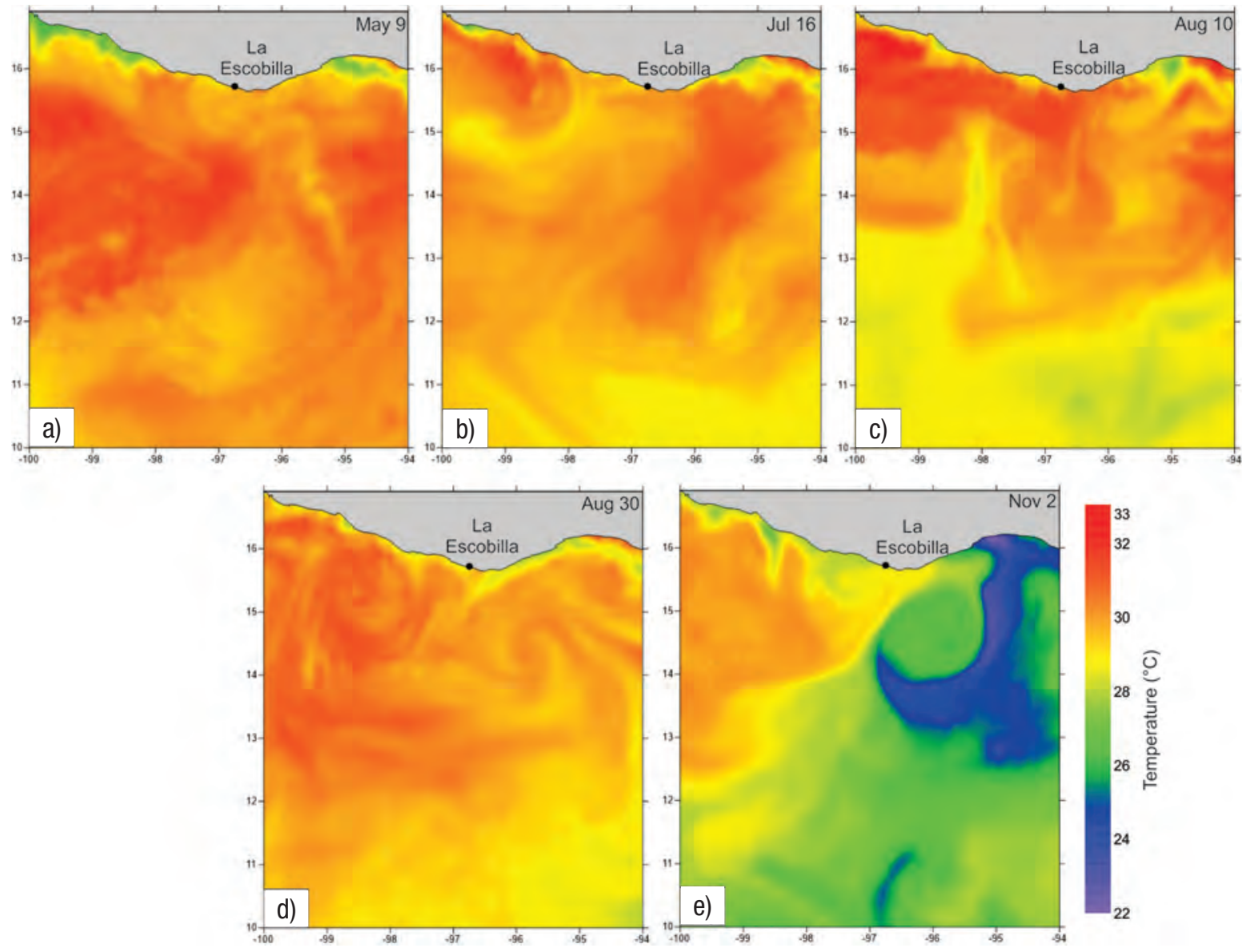

Figures 4a-e. Maps of Sea Surface Temperature $\left({ }^{\circ} \mathrm{C}\right.$ ) at each arribada event at La Escobilla, Oaxaca during 2005 on: a) May 9, 2005, b) July 16, 2005, c) August 10, 2005, d) August 30, 2005, e) November 2, 2005. 


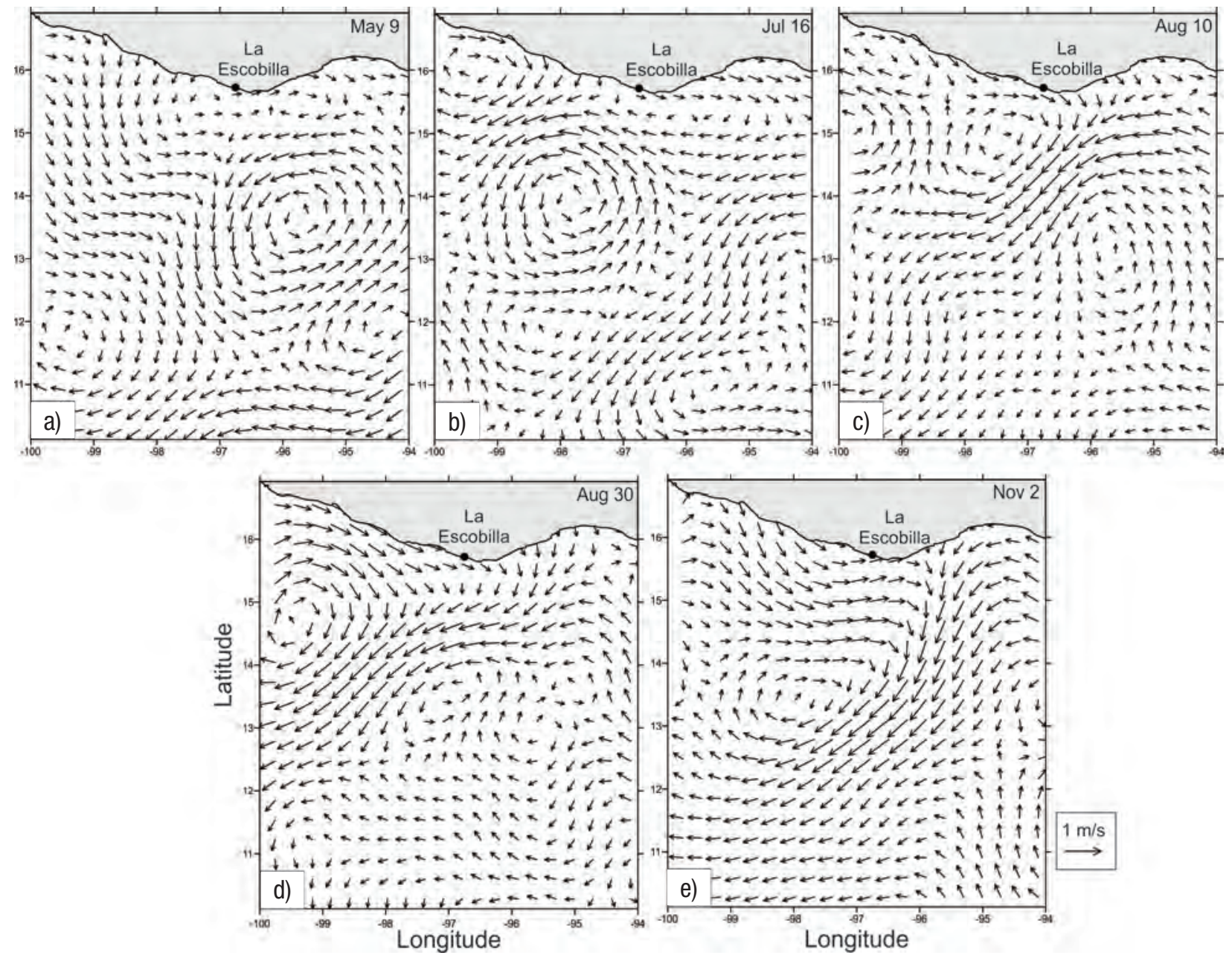

Figures 5a-e. Surface currents ( $\left.\mathrm{m} \mathrm{s}^{-1}\right)$ at each arribada event at La Escobilla, Oaxaca during 2005 on: a) May 9, 2005, b) July 16, 2005, c) August 10, 2005, d) August 30, 2005, e) November 2, 2005.

Much remains to be learned regarding the mechanisms that induce an arribada. Many aspects and more detailed studies are required to understand the population dynamics in order to design the most effective conservation methods and improve the management strategies for this endangered species, considering that this phenomenon is striking both in its rarity and unusual magnitude among turtles, even among large vertebrates. Understanding how ocean currents influence the distribution of these organisms remains a major challenge and an interesting subject for study. Recent advances in the use of small powered satellite transmitters attached to loggerhead turtles have documented the migrations that span thousands of kilometers in the North Atlantic (Mansfield et al., 2014) and Gulf of Mexico (Foley et al., 2013). Gaube et al. (2017) explored the possibility of tracking the trajectory of loggerhead sea turtles on maps of sea-level anomalies in order to understand their behavior. These studies revealed that by combining new technologies (e.g. satellite telemetry) with the trajectories of turtles, new understanding could be obtained about the ecology of these pelagic organisms. These methodologies can be applied in Mexico in order to improve our existing knowledge about the niche of this species.

\section{ACKNOWLEDGMENTS}

We thank the Comisión Nacional de Áreas Naturales Protegidas de México (CONANP) and the Centro Mexicano de la Tortuga (CMT), especially Cuauhtémoc Peñaflores, Ernesto Albavera, and Manelik Olivera, who facilitated field logistics and permits that allowed us to conduct the fieldwork at La Escobilla. We thank the Comisión Nacional del Agua (CONAGUA), Puerto Ángel, Oaxaca, for the meteorological data and the many volunteers who assisted in the fieldwork. Helpful comments of three anonymous reviewers are acknowledged.

\section{REFERENCES}

Amador, J. A., E. J. Alfaro, 0. G. Lizano \& V. O. Magaña. 2006. Atmospheric forcing of the Eastern tropical Pacific: a review. Progress in Oceanography 69: 101-142. DOI: 10.1016/j.pocean.2006.03.007.

Ballestero, J. 1996. Weather changes and olive ridley nesting in the Ostional Wildlife Refuge, Santa Cruz, Guanacaste, Costa Rica. In: 
Keinath, J. A., D. E. Barnard, J. A. Musick \& B.A. Bell (Eds.). Proceedings of the Fifteenth Annual Symposium on Sea Turtle Biology and Conservation. NOAA Technical Memorandum NMSF-SEFSC 387, USA, pp. 26-30.

Bernardo, J. \& P. T. Plotkin. 2007. An evolutionary perspective on the Arribada phenomenon and reproductive behavioral polymorphism of the olive ridley sea turtles (Lepidochelys olivacea). In: Plotkin, P. T. (Eds.). Biology and Conservation of Ridley Sea Turtles. Jonhs Hopkins University Press, Baltimore, USA, pp. 59-87.

Castellanos, P., E. J. D. Campos, I. Giddy \& W. Santis. 2016. Inter-comparison studies between high-resolution HYCOM simulation and observational data: The South Atlantic and the Agulhas leakage system. Journal of Marine Systems 159: 76-88. D0I: 10.1016/j. jmarsys.2016.02.010,

Chassignet, E. P., H. E. Hurlburt, O. M. Smedstad, G. R. Halliwell, P. J. Hogan, A. J. Wallcraft, R. Baralle \& R. Bleck. 2007. The HYCOM (Hybrid Coordinate Ocean Model) data assimilative. Journal of Marine Systems 65 (1-4): 60-83. D0I: 10.1016/j.jmarsys.2005.09.016.

Clusella-Trullas, S. \& F. V. Paladino. 2007. Micro-environment of olive ridley turtle nests deposited during an aggregated nesting event. Journal of Zoology 272: 367-376. DOI: 10.1111/j.14697998.2006.00277.x

Coles, W.C. \& J.A. Musick. 2000. Satellite Sea Surface Temperature Analysis and correlation with sea turtle distribution off North Carolina. Copeia 2000 (2): 551-554.

Coria-Monter, E., M. A. Monreal-Gómez, D. A. Salas de León, J. Aldeco-RamíREZ \& M. Merino-IBarRA M. 2014. Differential distribution of diatoms and dinoflagellates in a cyclonic eddy confined in the Bay of La Paz, Gulf of California. Journal of Geophysical Research-Oceans 119 (9): 6528-6268. DOI: 10.1002/2014JC009916.

Corneluus, S. E. 1982. Status of sea turtles along the Pacific coast of Middle America. In: Bjorndal, K. A. (Eds.). Biology and Conservation of Sea Turtles. Proceedings of the World Conference on Sea Turtle Conservation. Washington, D.C. 26-30 November 1979. Smithsonian Institution Press, Washington, D.C., pp. 211-219.

Corneluus, S. E. 1986. The Sea Turltes of Santa Rosa National Park. Fundación de Parques Nacionales. San José, Costa Rica. 64 p.

Corneluus, S. E. 1991. Lepidochelys olivacea. In: Janzen, D. H. (Eds.). Historia Natural de Costa Rica, Universidad de Costa Rica. San José, Costa Rica, pp. 407-410.

DASH, M. C. \& C. S. KAR. 1990. The Turtle paradise-Gahimartha: An Ecological Analysis and conservation strategy. Interprint Press, New Delhi, India. 295 p.

Duran-Campos, E., D. A. Salas de León, M. A. Monreal-Gómez, J. Aldeco-RaMírez \& E. CoriA-Monter. 2015. Differential zooplankton aggregation due to relative vorticity in a semi enclosed bay. Estuarine, Coastal and Shelf Science 164: 10-18. D0I: 10.1016/j.ecss.2015.06.030

FiedleR, P. C. \& L. D. Talley. 2006. Hydrography of the Eastern Tropical Pacific: A review. Progress in Oceanography 69 (2-4): 143-180. D0l: 10.1016/j.pocean.2006.03.008
Foley, A. M., B. A., Schroeder, R. Hardy, S. L., Mac Pherson, M. Nicholas \& M. S. CoYne. 2013. Postnesting migratory behavior of loggerhead sea turtles Caretta caretta from three Florida rookeries. Endangered Species Research 31: 129-142. D0I: 10.3354/esr00512

Fonseca, L. G., G.A. Murillo, L. Guadamúz, R. M. Spínola \& R. A. Valverde. 2009. Downward but stable trend in the abundance of arribada Olive Ridley sea turtles (Lepidochelys olivacea) at Nancite Beach, Costa Rica (1971-2007). Chelonian Conservation and Biology 81(1): 19-27. DOI: 10.2744/CCB-0739.1

Gaube, P., C. Barceló, D. J. McGillicuddy, Jr., A. Domingo, P. Miller, B. Giffoni, N. Marcovaldi \& Y. SWImmer. 2017. The use of mesoscale eddies by juvenile loggerhead sea turtles (Caretta caretta) in the southwestern Atlantic. PLOS ONE 12 (3): e0172839. DOI: 10.1371/journal. pone.0172839.

Hays, G. C., M. Dray, T. Qualfe, T.J. Smyth, N.C. Mironnet, P. Luschi, F. PapI \& M.J. BARNSLEY. 2001. Movements of migrating green turtles in relation to AVHRR derived sea surface temperature. International Journal of Remote Sensing 22 (8): 1403-1411.

HendRickson, J. R. 1980. The ecological strategies of sea turtles. American Zoologist 20: 597-608.

International Union OF Conservation of Nature. 2012. Red List of Threatened Species. IUCN Version 2012.1. www.iucnredlist.org

KeSSLER, W. S. 2006. The circulation of the eastern tropical Pacific: A review. Progress in Oceanography 69 (2-4): 181-217.

Luschi, P., G.C. Hays, C. Del-Seppia, R. Marsh \& F. Papl. 1998. The navigational feats of green turtles migrating from Ascension Island investigated by satellite telemetry. Proceedings of the Royal Society of London B 265: 2279-2284.

Luschi, P., G. C. Hays \& F. PaPı. 2003. A review of long movements by marine turtles and the possible role of ocean currents. Oikos 103: 293-302.

Lluch-Cota, S. E., Tripp-Valdez, M., Lluch-Cota, D. B., Lluch-Belda, D., Verbesselt, J., Herrera-Cervantes, H. \& J. J. Bautista-Romero. 2013. Recent trends in sea surface temperature of Mexico. Atmósfera 26 (4): 537-546.

Mansfield, K. L., J. Wyneken, W. P. Porter \& J. Luo. 2014. First satellite tracks of neonate sea turtles redefine the "lost years" oceanic niche. Proceedings of the Royal Society of London B: Biological Sciences 281 (1781): 20133039 . D0I: 10.1098/rspb.2013.3039.

Márquez, R., 0. Villanueva \& C. Peñaflores. 1976. Sinopsis de datos biológicos sobre la tortuga golfina Lepidochelys olivacea (Eschscholtz, 1829). INP Sinopsis sobre la Pesca No. 2. SIC-SP-INP, Mexico. 61 p.

Márouez, R. \& H. G. Van Disselt. 1982. A method for evaluating the number of massed nesting olive ridley sea turtles Lepidochelys olivacea, during an arribazon with comments on arribazon behavior. Netherlands Journal of Zoology 32: 419-425

Márquez, R., M. A. Carrasco, M. C. Jiménez, C. Peñaflores \& G. R. Bravo. 2005. Kemp's and olive ridley sea turtles population status. In: Coyne, M. S. \& R. D. Clark. (Eds.). Proceedings of the Twenty-First Annual Symposium on sea Turtle Biology and Conservation. NOAA Technical Memorandum NMFS-SEFSC-528, USA, pp. 237-239. 
MüLleR-Karger, F.E. \& C. Fuentes-Yaco. 2000. Characteristics of wind-generated rings in the Eastern tropical Pacific Ocean. Journal of Geophysical Research 105: 1271-1284. DOI: 10.1029/1999JC900257

Musıck, J. A. \& C. J. Limpus. 1997. Habitat utilization and migration in juvenile sea turtles. In: Lutz, P.L. \& J. A. Musick (Eds.). The Biology of Sea Turtles, Boca Raton. CRC Press, Costa Rica, pp. 137-163.

Palacios, D.M. \& S.J. Bograd. 2005. A census of Tehuantepec and Papagayo eddies in the northeast tropical Pacific. Geophysical Research Letters 32: L23606. DOI: 10.1029/2005GL024324.

Pandav, B., B. C. Choudhury \& K. Shanker. 1998. The Olive Ridley sea turtle (Lepidochelys olivacea) in Orissa: an urgent call for an intensive and integrated conservation programme. Current Science India 75: 1323-1328.

Peñaflores-Salazar, C., J. Vasconcelos-Pérez, E. Albavera-Padilla \& R. MÁrquez-Mllá́n. 2000. Twenty five years nesting of olive ridley sea turtle Lepidochelys olivacea in Escobilla beach, Oaxaca, Mexico. In: Abreu-Grobois, F.A., R. Briseño-Dueñas, R. Márquez \& L. Sarti. (Eds.). Proceedings of the eighteenth international sea turtle symposium. U.S. Dep. Commer. NOAA Tech. Memo. NMS-SEFSC, USA, pp. 27-29.

PLotKIN. P. T. 1994. Migratory and reproductive behavior of the olive ridley turtle Lepidochelys olivacea (Eschscholtz, 1829), in the eastern Pacific Ocean. Ph.D. diss. Texas A\&M University, College Station, Texas, USA, $166 \mathrm{p}$.

Plotkin, P. T., D. C. Rostal, R. A. Byles \& D. W. Owens. 1997. Reproductive and developmental synchrony in female Lepidochelys olivacea. Journal of Herpetology 31 (1): 17-22.

Polovina, J. J., G. H. Balazs, E. A. Howell, D. M. Parker, M. P. Sekı \& P. H. Dutton. 2004. Forage and migration habitat of loggerhead (Caretta caretta) and olive ridley (Lepidochelys oliveacea) sea turtles in the central North Pacific Ocean. Fisheries Oceanography 13 (1): 36-51. DOI: 10.1046/j.1365-2419.2003.00270.x
Polovina, J. J., I. Uchida, G. Balazs, E.A. Howell, D. Parker \& D. Dutton. 2006. The Kuroshio extension bifurcation region: a pelagic hotspot for juvenile loggerhead sea turtles. Deep Sea research Part II: Topical Studies in Oceanography 53: 326-339. D0I: 10.1016/j. dsr2.2006.01.006

Pritchard, P. C. H. 1997. Evolution, phylogeny and current status. In: Lutz, P. L. \& J. A. Musick (Eds.). The Biology of Sea Turtles. CRC Press, Florida, USA, pp. 1-28.

RiCHARDSON, W. J. 1990. Wind and orientation of migrating birds: a review. In: Berthold, P. (Eds.). Orientation in birds. Birkahuser Verlag, Germany, pp. 226-249.

Shanker, K., B. Pandav \& B. C. Choudhury. 2003. An assessment of the olive ridley turtle (Lepidochelys olivacea) nesting population in Orissa, India. Biological Conservation 115: 149-160. D0I: 10.1016/S00063207(03)00104-6

Solow, A. R., K. A. BJoRndal \& A. B. Bolten. 2002. Annual variation in nesting numbers of marine turtles: the effect of sea surface temperature on re-migration intervals. Ecology Letters 5: 742-746.

ThaCKer, W. C., S. K. Lee \& G. R. HAlliwell JR. 2004. Assimilating 20 years of Atlantic XBT data into HYCOM: a first look. Ocean Modelling 7 (1-2): 183-210. D0l: 10.1016/j.ocemod.2003.08.002

Valverde, R. A., S. E. Corneluus \& C. L. Mo. 1998. Decline of the olive ridley sea turtle (Lepidochelys olivacea) nesting assemblage at Nancite beach, Santa Rosa National Park, Costa Rica. Chelonian Conservation and Biology 3: 58-63.

Valverde, R. A., C. M. Orrego, M. T. Tordoir, F. M. Gómez, D. S. Solís, R. A. Hernández, G. B. Gómez, L. S. Brenes, J. P. Baltodano, L. G. Fonseca \& J. R. SpotILA. 2012. Olive Ridley Mass Nesting Ecology and Egg Harvest at Ostional Beach, Costa Rica. Chelonian Conservation and Biology 11 (1): 1-11. D0I: 10.2744/CCB-0959.1

Willet, C. S., R. Leben \& M. F. Lavín. 2006. Eddies and mesoscale processes in the eastern tropical Pacific: A review. Progress in Oceanography 69 (2-4): 218-238. DOI: 10.1016/j.pocean.2006.03.010. 